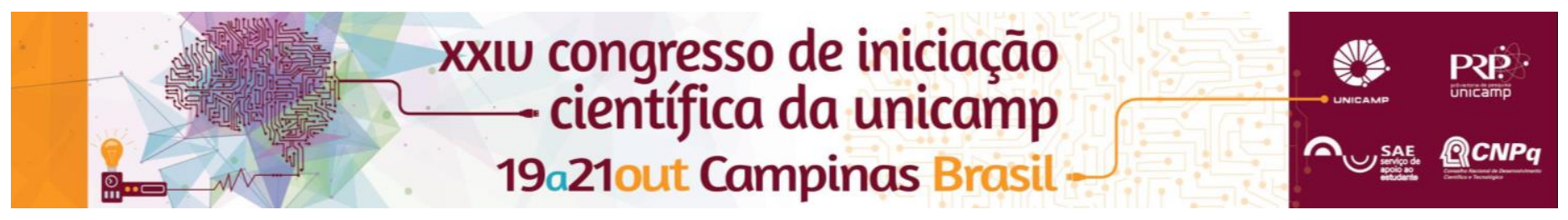

\title{
PLA modification with elastomer for plasticizing and flexibilisation.
}

\section{Lucas Patero*, Ana R. Morales, Mayara P. Calderaro, Caroline N. Kuchnier.}

\section{Abstract}

The poly (lactic acid) PLA is a biodegradable polymer with great potential due to its versatility, obtention ease and relatively low cost of production. However, it has some application limitations because it's hard at room temperature. It is sought, therefore, by physical modification, its flexibilisaton and plasticizing by reduction of its glass transition temperature $(\mathrm{Tg})$. It was seen as promising its physical modification with an elastomer. From literature searches, we opted for this work to use two core-shell elastomer with same composition, but synthesized in different conditions. This choice was made because of the existence of polar groups on the elastomer that can interact with PLA. Furthermore, the itaconic acid monomer used for the synthesis of these elastomers are from renewable sources (Zborowski, 2015). PLA samples were prepared with elastomer core-shell type by melting and pressing. Samples were analyzed in order to obtain the characterization of the obtained blends.

\section{Key words:}

Poly (lactic acid), elastomers, flexibilisation.

\section{Introduction}

Although PLA is a biodegradable polymer with potential application in the packaging sector, disadvantages as narrow processing window and low thermal stability limit their use ${ }^{1}$. Thus, this work aims at easing the material by incorporating core-shell rubber particles that are composed of two layers, one internal (core) and other outer (shell). The elastomer used in this work is experimental and was developed by Zborowski (2015). It consists of core-shell particles of poly (acrylate-butyl methacrylate-co-methyl) synthesized in the presence of itaconic $\mathrm{acid}^{2}$. The carboxylic groups derived from itaconic acid can promote chemical interaction between the PLA and the elastomer.

\section{Results and Discussion}

The research followed the following order:
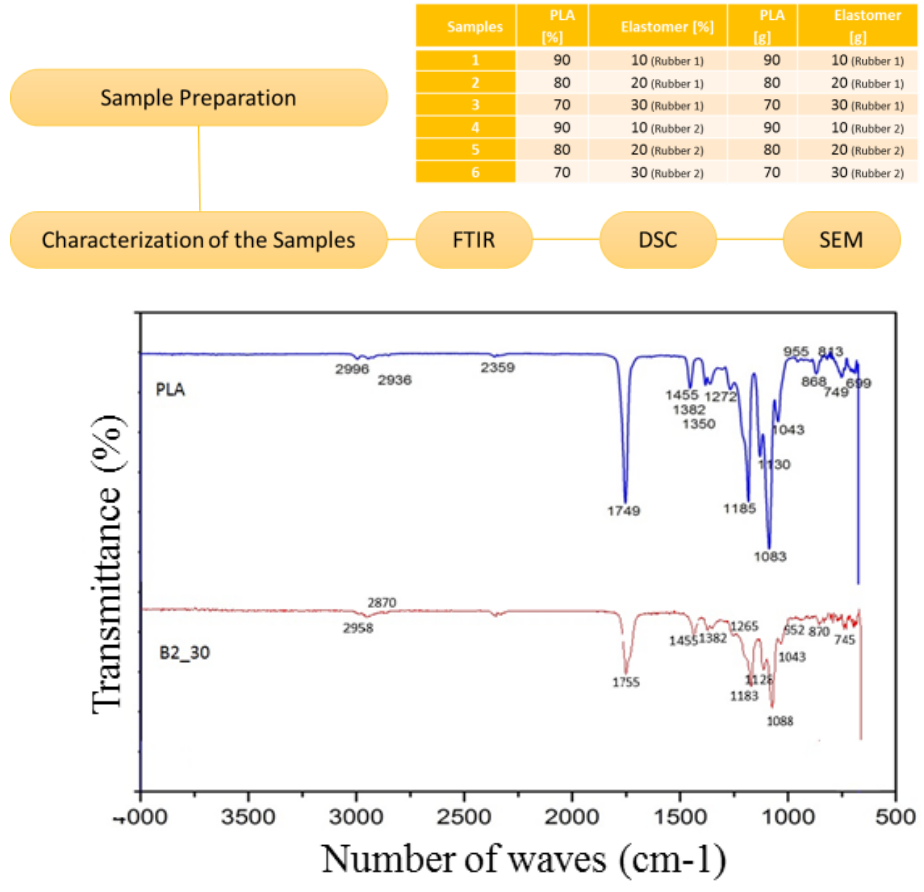

Figure 1. spectrogram IR PLA Pure and B2_30.

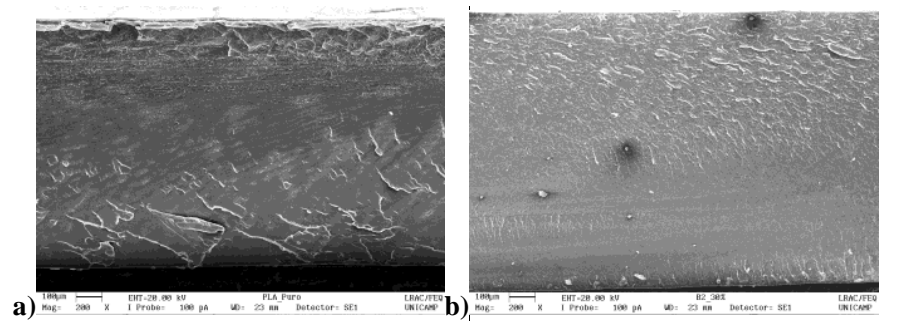

Figure 2. Micrographs (a) PLA Pure (b) B2_30.

Chart 1. Data of $\mathrm{Tg}$ in ${ }^{\circ} \mathrm{C}$ (glass transition) of the materials.

\begin{tabular}{|c|c|c|}
\hline$\underline{\text { Sample }}$ & $\frac{\text { Rubbery }}{\text { Phase }}$ & $\frac{\underline{\text { Glassy }}}{\text { phase }}$ \\
\hline PLAPure & - & 60 \\
\hline B1 Pure & -29 & - \\
\hline B2 Pure & -27 & - \\
\hline B1_10 & -32 & 60 \\
\hline B1_20 & -34 & 60 \\
\hline B1_30 & -33 & 60 \\
\hline B2_10 & -26 & 60 \\
\hline B2_20 & -32 & 59 \\
\hline B2_30 & -32 & 59 \\
\hline
\end{tabular}

\section{Conclusions}

The results of FTIR and SEM indicated that there were no significant changes in structure and morphology of the PLA after the addition of rubbers. In addition, thermal analysis showed that this system does not allow the flexibilisation of the polymer, therefore it is important to search for new alternatives.

\section{Acknowledgement}

The authors would like to thank CNPq.

${ }^{1}$ AL-ITRY, R.; LAMNAWAR, K.; MAAZOUZ, A. Improvement of thermal stability, rheological and mechanical properties of PLA, PBAT and their blends by reactive extrusion with functionalized epoxy. Polymer Degradation and Stability, p. 1-17, 2012.

2 ZBOROWSKI, L.; PORTO, D.; TAPARELLI, J., R.; MEI, L., H., I Influência de temperatura e de ácido itacônico na síntese de partículas coreshell de acrilato de butila e metacrilato de metila via polimerização em emulsão em processo semi-contínuo. Anais do $13^{\circ}$ Congresso Brasileiro de Polímeros, 2015. 